\title{
Structural Analysis of Ag Agglomeration in Ag-based Ohmic Contact to p-type GaN
}

\author{
J. H. Son, Y. H. Song, and J. -L. Lee* \\ Department of Material Science and Engineering, Pohang University of Science and Technology, Pohang 790-784 \\ (Received September 1, 2010, Revised November 9, 2010, Accepted November 10, 2010)
}

We investigate the crystallographic orientation and strain states of the $\mathrm{Ni} / \mathrm{Ag}$ ohmic contacts on p-type GaN. The Ag film in the Ni/Ag contact was severely agglomerated during high temperature annealing in air ambient. As a results, after annealing for $24 \mathrm{~h}$, the Ni/Ag contact shows non-linear $I-V$ curve and low light reflectance of $\sim 21 \%$ at $460 \mathrm{~nm}$ wavelength. High-resolution X-ray diffraction results show that the interplanar spacing of Ag (111) planes is almost same to that of bilk $\mathrm{Ag}$ after annealing for $24 \mathrm{hrs}$, indicating that the in-plane tensile strain in the Ag film was fully relaxed due to the Ag agglomeration.

Keywords : p-GaN, Reflective ohmic contact, Ag agglomeration, Light-emitting diode

\section{Introduction}

GaN-based light-emitting diodes (LEDs) are attracting great interest as candidates for next generation solid-state lighting, because of their long lifetime, small size, high efficacy, and low energy consumption. Recently, vertical-structure device by laser lift-off (LLO) have been exploited for high power and high efficiency LEDs which are suitable for general illumination applications [1-6]. In this configuration, highly reflective and low resistance ohmic contacts to p-type GaN are key aspects to reduce forward voltage and improve the light extraction efficiency. Low contact resistivity $\left(\sim 10^{-5} \Omega \mathrm{cm}^{2}\right)$ and high reflectance $(>80 \%)$ could be obtained using various $\mathrm{Ag}$-based ohmic contacts [2-7]. Although the thermal stability of the $\mathrm{Ag}$-based contacts can be improved by using contact layers and/or overlayers of refractory metals [2,5,7], and Ag alloy-based contact
[6], it is still not enough for $\sim 105$ hours of device operation, because Ag films have poor adhesion to the substrate and easily agglomerate at elevated temperatures in air ambient. However, the microstructural evolutions of $\mathrm{Ag}$-based ohmic contact by $\mathrm{Ag}$ agglomeration have not been investigated yet.

In this letter, we investigate the microstructural evolution of the $\mathrm{Ni} / \mathrm{Ag}$ ohmic contacts to $\mathrm{p}$-type GaN as a function of annealing time using high-resolution $\mathrm{x}$-ray diffraction (HRXRD). As the annealing time increases, the $\mathrm{Ni} / \mathrm{Ag}$ contact was severely agglomerated, resulting in the increase of contact resistivity and decrease of light reflectance. Combining the microstructural analysis with experimental data of surface morphology, contact resistivity, and light reflectance, the origin of the $\mathrm{Ag}$ agglomeration of $\mathrm{Ag}$-based reflective Ohmic contact was investigated.

*[전자우편] jllee@postech.ac.kr 


\section{Experiments}

$\mathrm{Mg}$-doped p-type GaN films used in this work were grown on (0001) sapphire substrate by metal organic chemical vapor deposition (MOCVD) [8]. Details on the wafer are described in previous works [2]. For measurements of specific contact resistivity using the transmission line method (TLM), active regions were defined by inductively coupled plasma of $\mathrm{Cl}_{2} / \mathrm{BCl}_{3}$ gas, followed by dipping samples into a boiling aqua regia solution of $\mathrm{HCl}: \mathrm{HNO}_{3}(3: 1)$ to remove surface oxides [9]. Figure 1(a) shows the schematic illustration of TLM test pattern formed on the p-type GaN. The contact resistance $\left(r_{\mathrm{c}}\right)$ in the unit of $\Omega \mathrm{cm}$ and the sheet resistance $\left(R_{\mathrm{S}}\right)$ in the unit of $\Omega / \square$ are determined from the intercept of $y$-axis and the slope of resistance at $0 \mathrm{~V}$ with interspacing of TLM pads, as plotted in Fig. 1(b). The contact resistivity $\left(\rho_{\mathrm{c}}\right)$ could be calculated by $\rho_{\mathrm{c}}=r_{\mathrm{c}}^{2} / \mathrm{R}_{\mathrm{s}}$. TLM test structure with $100 \times 50 \mu^{2}$ pads was patterned on the surfacetreated samples using photoresist. Prior to metal deposition, all the samples were dipped in $\mathrm{HCl}: \mathrm{DI}$ (1:1) solution for $2 \mathrm{~min}$. After the $\mathrm{HCl}$ treatment, $\mathrm{Ni} / \mathrm{Ag}(10 / 1800 \AA$ A $)$ metals were deposited by electron beam evaporation under a base pressure of $2 \times 10^{-7}$

(a)

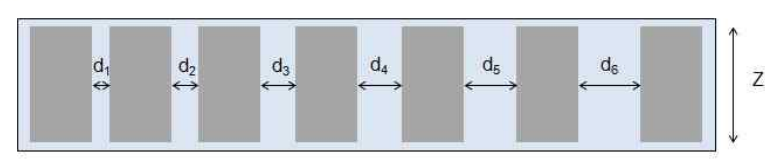

(b)

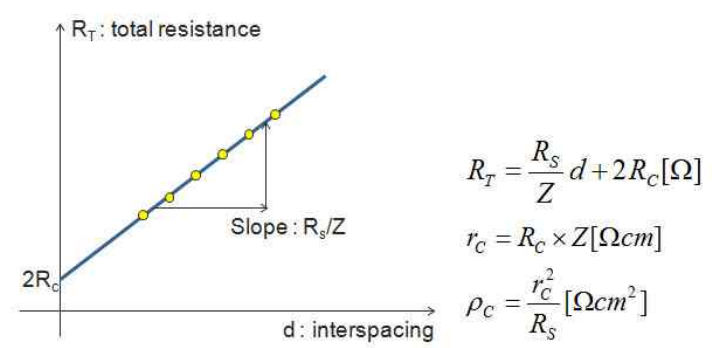

Figure 1. (a) Schematic illustration of TLM test pattern and (b) evaluation method of contact resistivity using TLM. torr. After lift-off of metals deposited on the photoresist, the samples were annealed at $500^{\circ} \mathrm{C}$ in air ambient. Current-voltage $(I-V)$ characteristics of the contacts were examined using a HP4156 semiconductor parameter analyzer. A tungsten-halogen lamp and a monochromator were used for measuring the light reflectance of the contacts. The reflected beam at the incident angle of $45^{\circ}$ was collimated to a photomultiplier tube. An Ag mirror with the certified reflectance of $\sim 95 \%$ in the wavelength range of interest was used as the reflectance standard. Synchrotron radiation photoemission spectroscopy (SRPES) and high-resolution X-ray diffraction (HRXRD) measurements of the contact were carried out to evaluate the microstuructural evolution of the contacts. HRXRD $\theta-2 \theta$ scans were performed by
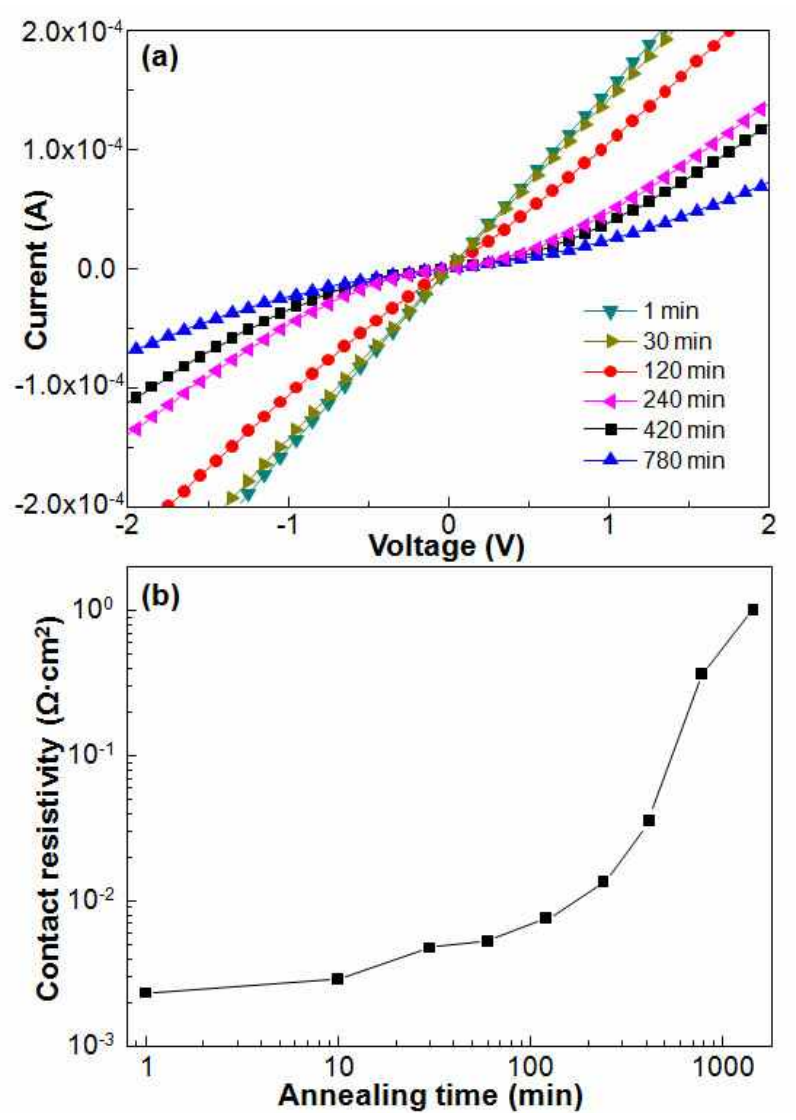

Figure 2. (a) Current-voltage $(I-V)$ curves and (b) changes of contact resistivity for the $\mathrm{Ni} / \mathrm{Ag}$ contact as a function of annealing time at $500^{\circ} \mathrm{C}$ in air ambient. 
angular resolution of $0.002^{\circ}$ using a high-resolution four-axis X-ray diffractometer with a 4-bounce crystal and 3-bounce Ge (220) analyzer crystal.

\section{Results and discussion}

Fig. 2 shows the $I-V$ curves and contact resistivity of the $\mathrm{Ni} / \mathrm{Ag}$ contact as a function of annealing time at $500^{\circ} \mathrm{C}$ in air ambient. The annealing temperature of $500^{\circ} \mathrm{C}$ was chosen to clearly investigate the changes of microstructure in the $\mathrm{Ni} / \mathrm{Ag}$ contact by $\mathrm{Ag}$ agglomeration, although the $\mathrm{Ni} / \mathrm{Ag}$ contact shows the lowest contact resistivity order of $\sim 10^{-5} \Omega \mathrm{cm}^{2}$ and highest light reflectance about $90 \%$ after annealing at $300^{\circ} \mathrm{C}$, as previously reported [2]. After annealing for 1 min, the Ni/Ag contact showed the contact resistivity of $2 \times 10^{-3} \Omega \mathrm{cm}^{2}$ and good ohmic characteristics. However, as the annealing time increases, the contact resistivity of the contact was significantly increased, and the contact exhibits a nonlinear $I-V$ behavior after annealing for $240 \mathrm{~min}$.

SRPES measurements were carried out to investigate the ohmic formation mechanism of the contacts. Fig. 3 shows the SRPES spectra of (a) Ga3d and (b) $\mathrm{N} 1 s$ core levels before and after annealing. The Ga3d peaks were deconvoluted into three bonds, corresponding to $\mathrm{Ga}-\mathrm{O}, \mathrm{Ga}-\mathrm{N}$, and metallic $\mathrm{Ga}$ bonds,
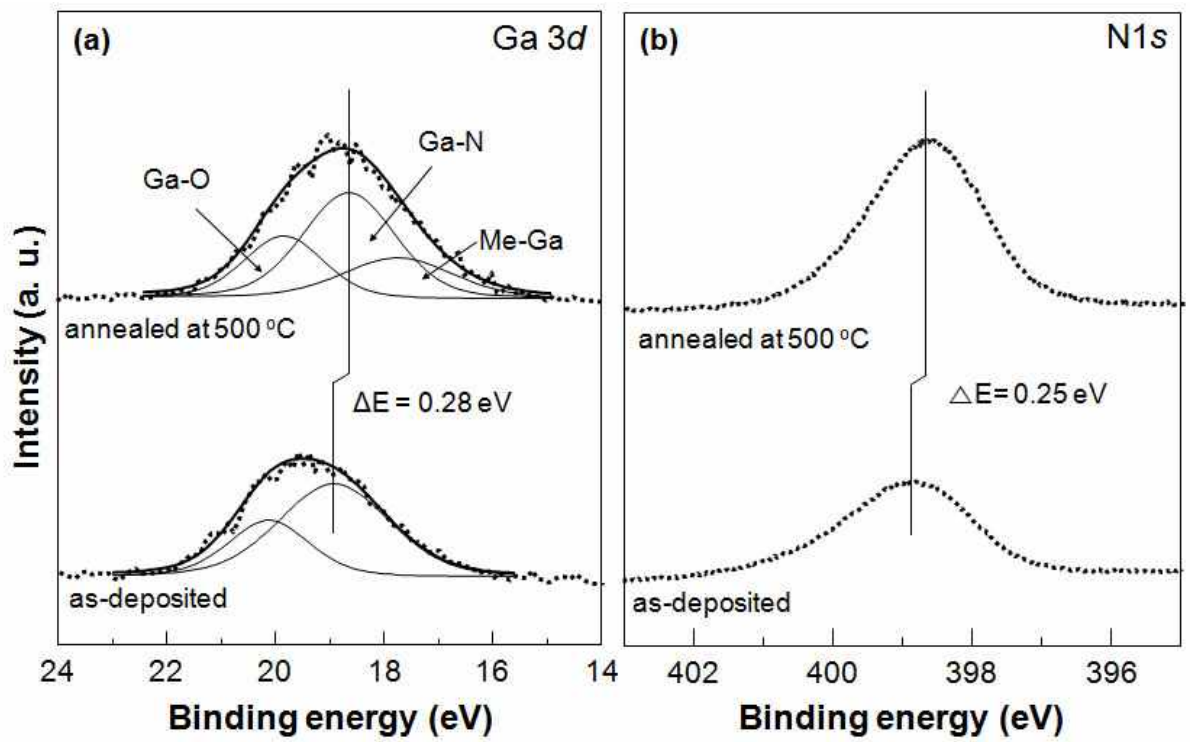

(c)

As-deposited

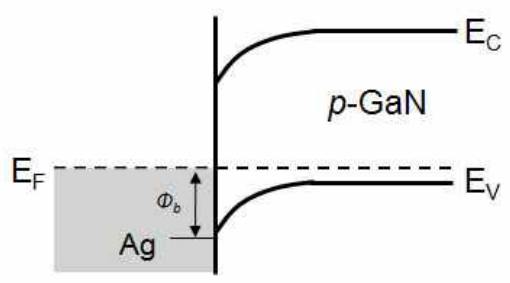

After annealing

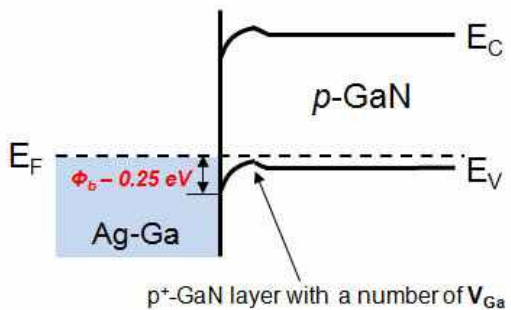

Figure 3. SRPES spectra of (a) Ga3d and (b) N1s core levels for the Ag (20 $\AA$ ) contacts before and after annealing for $1 \mathrm{~min}$ at $500^{\circ} \mathrm{C}$ in air ambient. (c) Schematic energy band diagram below the interface of the $\mathrm{Ag}$ metal with $\mathrm{p}$-type GaN before and after annealing. 
respectively. After annealing at $500^{\circ} \mathrm{C}$ in air ambient, the peak intensity of metallic Ga bonds was significantly increased. It means that the out-diffusion $\mathrm{Ga}$ atoms to $\mathrm{Ag}$ layer was promoted by the oxidation annealing, as previously reported [10]. Furthermore, the binding energies of the peaks decreased after annealing, indicating the reduction of Schottky barrier height for the transport of holes at metal/GaN interface. Based on SRPES results, the schematic energy band diagram at the $\mathrm{Ag} / \mathrm{p}$-type $\mathrm{GaN}$ interface before and after annealing at $500^{\circ} \mathrm{C}$ in air are shown in Fig. 3(c).

The light reflectance spectra and the changes in the light reflectance at $460 \mathrm{~nm}$ wavelength for the
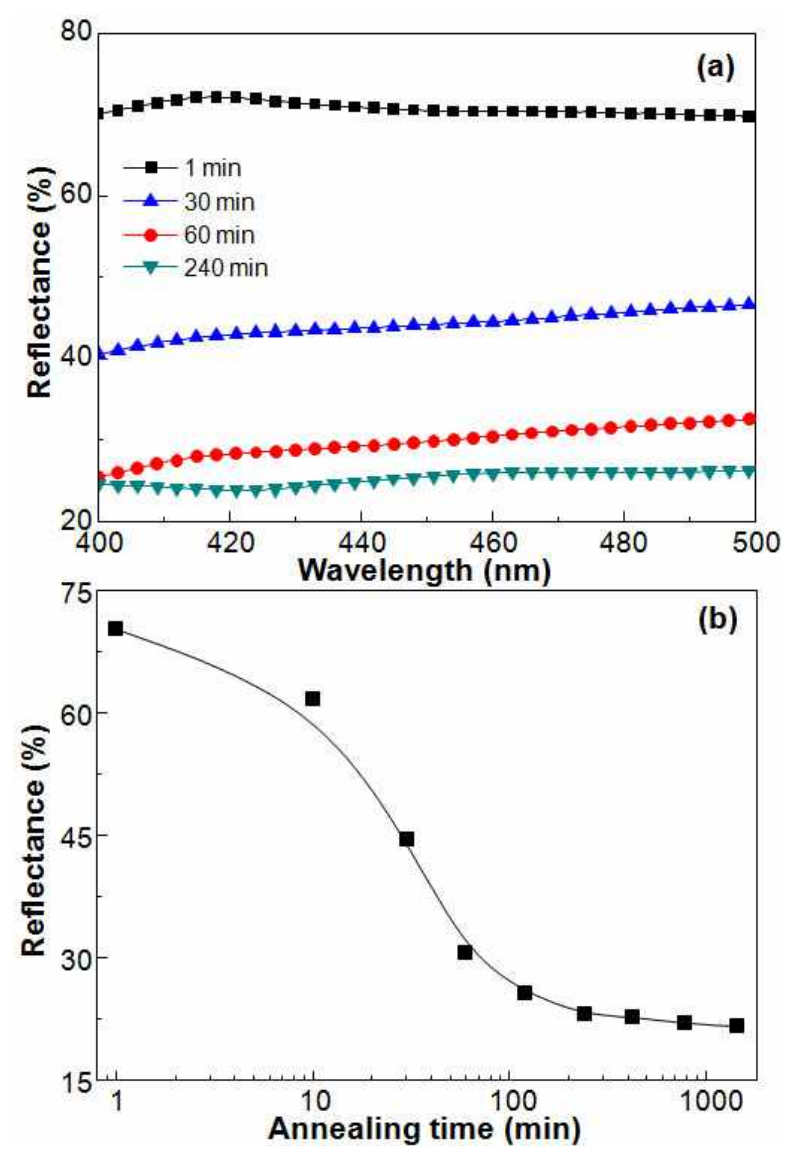

Figure 4. (a) Light reflectance spectra and (b) changes of light reflectance at $460 \mathrm{~nm}$ wavelength for the $\mathrm{Ni} / \mathrm{Ag}$ contact as a function of annealing time at $500^{\circ} \mathrm{C}$ in air ambient.
$\mathrm{Ni} / \mathrm{Ag}$ contact as a function of annealing time were shown in Fig. 4(a) and (b). The light reflectance of $70 \%$ was measured after annealing for $1 \mathrm{~min}$, but it was rapidly degraded with annealing time. Finally, after annealing for $24 \mathrm{hrs}$, the light reflectance was decreased to $21 \%$.

Fig. 5 displays the scanning electron microscopy (SEM) micrographs of the $\mathrm{Ni} / \mathrm{Ag}$ contact after annealing at $500^{\circ} \mathrm{C}$ as a function of annealing time. The annealed Ni/Ag contact for 1 min shows the small voids, and the surface roughness and voids were increased with annealing time. After annealing for 24 hrs, the Ni/Ag contact shows fully agglomerated surface with $\mathrm{Ag}$ islands and voids. The degradations in the contact resistivity and light reflectance of the contact shown in Fig. 2 and 4 were attributed to the severe $\mathrm{Ag}$ agglomeration in the $\mathrm{Ni} / \mathrm{Ag}$ contact.

In order to examine the crystallographic changes of the contact with annealing time, HRXRD $\theta-2 \theta$ scans were performed in the $\mathrm{Ni} / \mathrm{Ag}$ contact as a function of annealing time. As previously reported, only $\mathrm{Ag}$ (111) diffraction peaks are shown in Fig. 6(a), because the $\mathrm{Ag}$ film is epitaxially grown on $\mathrm{p}$-type GaN with thin $\mathrm{Ni}$ contact layer [2]. The inset shows the enlarged Ag (111) peaks to clearly show the peak shift with annealing time. As the annealing time increases, the peak intensity was gradually increased and the full-width at half-maximum (FWHM) was decreased. Moreover, the Ag (111) peaks were moved toward lower diffraction angle with annealing time.

The interplanar spacing, $d$, can be evaluated from the $2 \theta$ positions in the $\theta-2 \theta$ scans of the $\mathrm{Ni} / \mathrm{Ag}$ contact as shown in Fig. 6(b). After annealing for 1 min, the Ni/Ag contact shows shorter $d$ spacing than bulk Ag (2.359 ̊̊) [11], meaning that Ag film is under in-plane tensile strain. However, $d$ spacing was drastically increased with annealing time, and the $\mathrm{Ni} /$ Ag contact shows almost same $d$-spacing compared to bulk Ag after annealing for $24 \mathrm{hrs}$. These results indicate that the tensile strain in $\mathrm{Ag}$ film was 

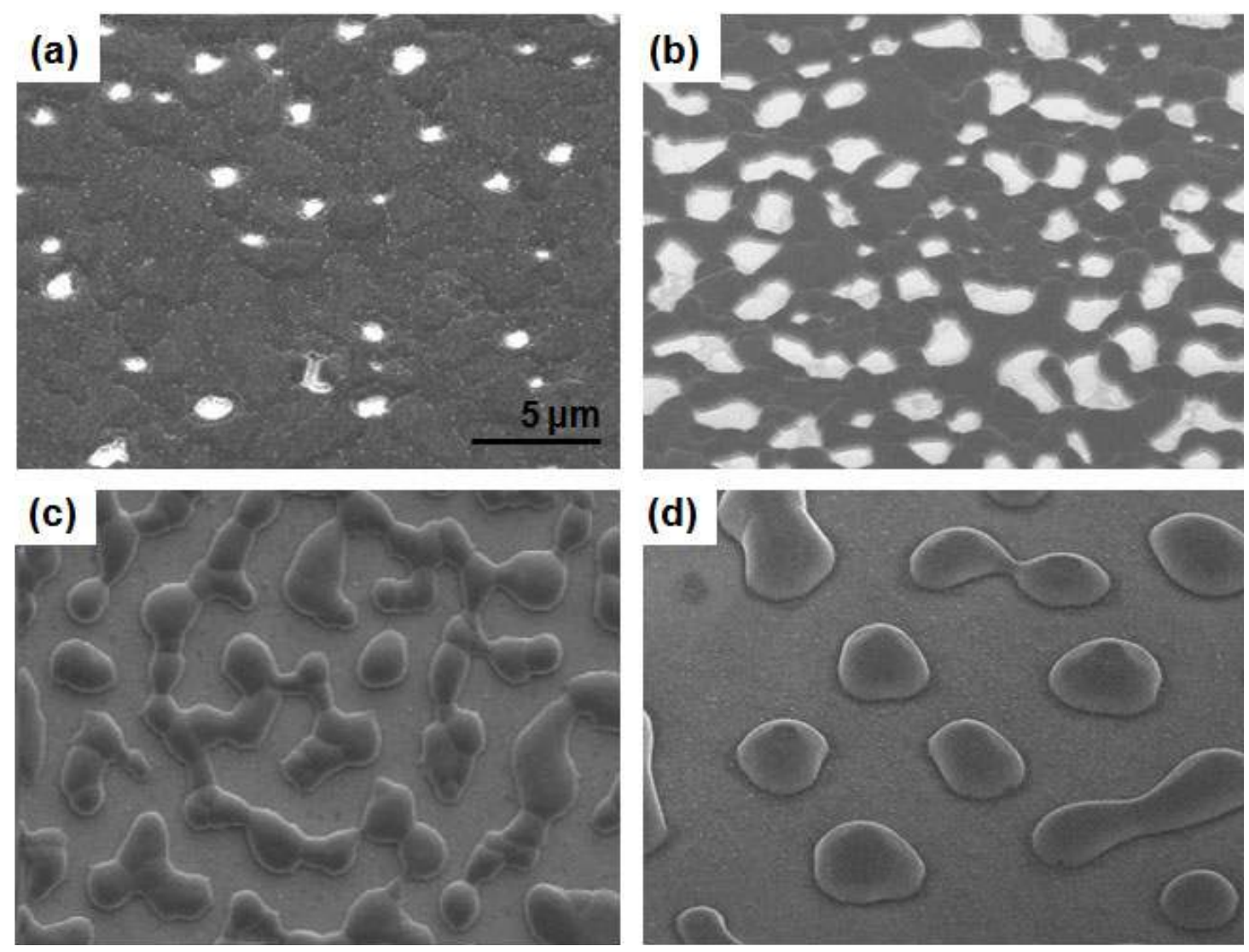

Figure 5. SEM micrographs of the Ni/Ag contact after annealing for (a) 1 min, (b) 30 min, (c) 120 min and (d) $420 \mathrm{~min}$ at $500^{\circ} \mathrm{C}$ in air ambient.

gradually relaxed as the agglomeration was occurred, and finally unstrained $\mathrm{Ag}$ film due to fully agglomerated Ag film.

Ohmic contact formation of the $\mathrm{Ni} / \mathrm{Ag}$ contact is the formation of $\mathrm{Ag}-\mathrm{Ga}$ solid-solution due to the $\mathrm{Ga}$ out-diffusion to Ag layer after annealing [10]. The formation of $\mathrm{Ag}-\mathrm{Ga}$ solid solution leaves Ga vacancies below the contact. Because Ga vacancies act as shallow acceptors for electrons in GaN, the net hole concentration at the metal/GaN interfacial region increased, resulting in the low contact resistivity of $\mathrm{Ag}$-based Ohmic contact. In spite of the formation of $\mathrm{Ag}-\mathrm{Ga}$ solid solution, the degradation in contact resistivity of the contacts after long time annealing could be attributed to the increase of uncovered region due to the severe $\mathrm{Ag}$ agglomeration as shown in Fig. 5. Agglomeration of $\mathrm{Ag}$ film is a mass trans- port process to reduce total free of the film during high temperature annealing [12]. The surface diffusion driven by both surface energy and surface stress results in the grain boundary grooving, hillocks and/or volids formation, and finally agglomeration [13]. For the Ag film, Ag atoms in other planes move toward (111)-oriented ones to reduce the surface energy, leading to $\mathrm{Ag}$ agglomeration, because the (111)-oriented planes are energetically most stable [12]. For the Ni/Ag contact, the Ag film is epitaxially grown on p-type GaN with (111) orientation. Thus, the surface diffusion of $\mathrm{Ag}$ atoms to reduce the surface energy could be reduced. However, the thermal compressive stress generated during annealing due to the difference in coefficient of thermal expansion between film and substrate is another driving force for the Ag agglomeration [14]. The Ag film in 

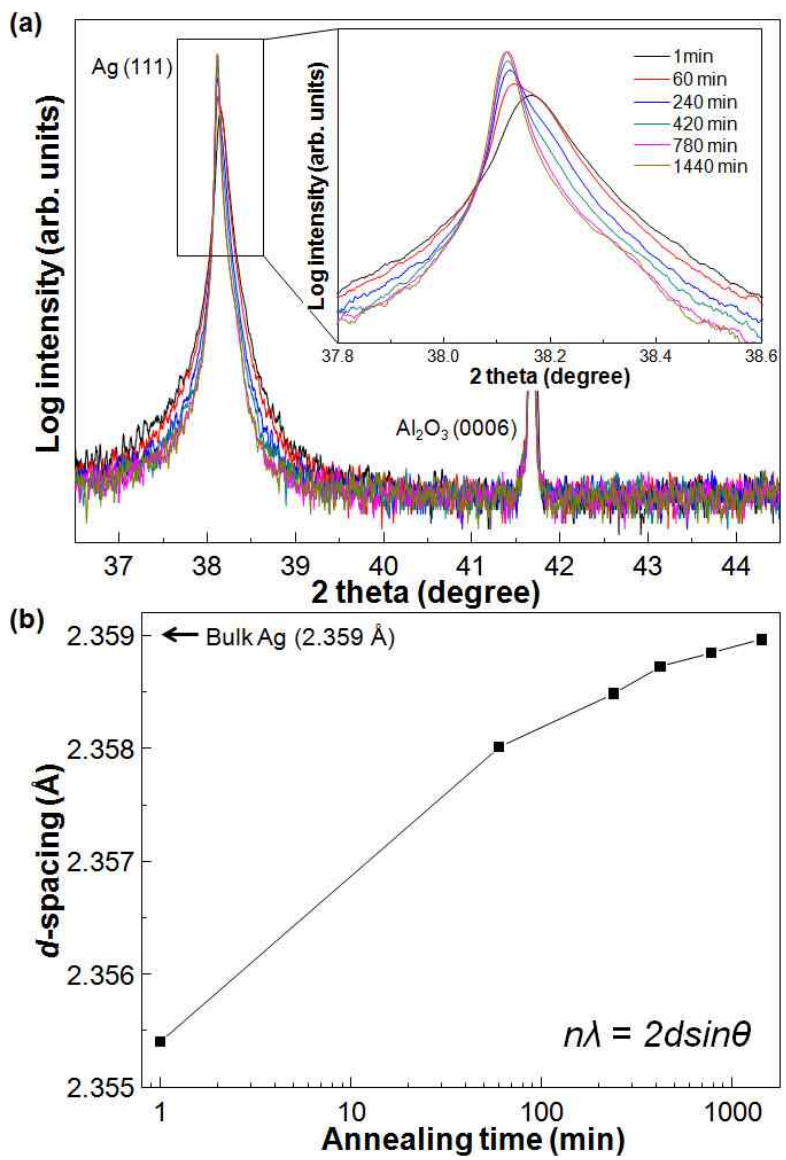

Figure 6. (a) HRXRD $\theta-2 \theta$ profiles of the Ni/Ag contact as a function of annealing time at $500^{\circ} \mathrm{C}$ in air ambient. Inset shows the enlarged $\mathrm{Ag}$ (111) peaks of $\mathrm{Ni} / \mathrm{Ag}$ contact. (b) Interplanar, d, spaing of the $\mathrm{Ag}$ (111) planes in the $\mathrm{Ni} / \mathrm{Ag}$ contact as a function of annealing time.

the annealed $\mathrm{Ni} / \mathrm{Ag}$ contact at $500^{\circ} \mathrm{C}$ for $1 \mathrm{~min}$ is under in-plane tensile strain due to the lattice constant mismatch as shown in Fig. 6. This tensile strain was gradually relaxed with annealing time due to $\mathrm{Ag}$ agglomeration, resulting in the shift of $\mathrm{Ag}$ (111) peaks toward lower diffraction angle and subsequently increase of $d$-spacing toward bulk Ag (Fig. $6)$.

\section{Conclusion}

In conclusion, we investigated the effects of $\mathrm{Ag}$ agglomeration on the crystallographic orientation of
$\mathrm{Ag}$-based ohmic contacts on p-type GaN. The contact resistivity and light reflectance were severely degraded due to the $\mathrm{Ag}$ agglomeration in the $\mathrm{Ni} / \mathrm{Ag}$ contact. The tensilely strained $\mathrm{Ag}$ film in the $\mathrm{Ni} / \mathrm{Ag}$ contact shows the strain relaxation during annealing due to the $\mathrm{Ag}$ agglomeration. We propose that understanding the crystallographic evolutions of the contact metals during annealing is a key aspect to develop high-quality reflective ohmic contacts for high-performance GaN-based LEDs of solid-state lighting.

\section{Acknowledgements}

This work was supported in part by Priority Research Centers Program through the National Research Foundation of Korea (NRF) funded by the Ministry of Education, Science and Technology (2009-0094037), and in part by the Industrial Technology Development Program funded by the Ministry of Knowledge Economy (MKE, Korea).

\section{References}

[1] J. K. Kim and E. F. Schubert, Opt. Express 16, 21835 (2008).

[2] J. H. Son, Y. H. Song, H. K. Yu, and J.-L. Lee, Appl. Phys. Lett. 95, 062108 (2009).

[3] T. Y. Nam, D. H. Kim, W. H. Lee, S. J. Kim, B. G. Lee, T. G. Kim, Y. C. Jo, and Y. S. Choi, J. Korean Vacuum Soc. 19, 10 (2010).

[4] C. H. Chou, C. L. Lin, Y. C. Chung, H. Y. Bor, and C. Y. Liu, Appl. Phys. Lett. 90, 022103 (2007).

[5] L. -B. Chang, C. -C. Shiue, and M. -J. Jeng, Appl. Phys. Lett. 90, 163515 (2007).

[6] G. H. Jung, J. H. Son, Y. H. Song, and J. -L. Lee, Appl. Phys. Lett. 96, 201904 (2010).

[7] S. Kim, J. -H. Jang, and J. -S. Lee, J. Electrochem. 
Soc. 154, H973-H976 (2007).

[8] K. -H. Kim, I. -S. Kim, H. -B. Park, I. -H. Bae, J. -I. Yu, and Y. -S. Jang, J. Korean Vacuum Soc. 18, 37 (2009)

[9] J. -L. Lee, M. H. Weber, J. K. Kim, and K. G. Lynn, Appl. Phys. Lett. 78, 4142 (2001).

[10] H. W. Jang, J. H. Son, and J. -L. Lee, J. Electrochem. Soc. 155, H563 (2008).
[11] JCPDS Card No. 04-0783.

[12] H. C. Kim, N. D. Theodore, and T. L. Alford, J. Appl. Phys. 95, 5180 (2004).

[13] D. J. Srolovitz, Acta Metall. 37, 621 (1989).

[14] G. F. Malgas, D. Adams, P. Nguyen, Y. Wang, T. L. Alford, and J. W. Mayer, J. Appl. Phys. 90, 5591 (2001). 


\title{
고분해능 $\mathrm{X}$ 선 회절을 이용한 $\mathrm{Ag}$ 기반 $\mathrm{p}$ 형 반사막 오믹 전극 집괴 분석 \\ 손준호 · 송양희 · 이종람*
}

포항공과대학교 신소재공학과, 포항 790-784

(2010년 9월 1일 받음, 2010년 11월 9일 수정, 2010년 11월 10일 확정)

\begin{abstract}
본 연구에서는 고분해능 X선 회절법을 이용해 $\mathrm{Ni} / \mathrm{Ag}$ 반사막 $\mathrm{p}$ 형 오믹 전극의 $\mathrm{Ag}$ 집괴에 따른 전극의 구조 분석을 수행하였 다. 대기 분위기에서 오믹 전극을 고온 열처리할 경우, 열처리 시간이 증가할수록 $\mathrm{Ag}$ 의 집괴가 진행되어 24 시간 열처리 후, 전류-전압 곡선은 쇼트키 특성을 나타내었고, 또한 $460 \mathrm{~nm}$ 파장에서 $21 \%$ 의 낮은 반사도를 나타내었다. X선 회절 결과로부터 $\mathrm{Ag}$ 의 집괴가 진행될수록, $\mathrm{Ag}$ 박막의 내부 변형율을 감소되는 방향으로 $\mathrm{Ag}$ 원자의 확산이 진행되어, $\mathrm{Ag}$ (111) 결정면의 면간 거리가 bulk $\mathrm{Ag}$ 와 거의 동일하게 나타났다. 이러한 반사막 오믹 전극의 구조 분석은 고출력 고효율 수직형 LED에 적합한 열 적 안정성이 우수한 오믹 전극의 개발에 매우 중요함을 알 수 있다.
\end{abstract}

주제어 : p형 $\mathrm{GaN}$, 반사막 오믹 전극, $\mathrm{Ag}$ 집괴, 발광다이오드

* [전자우편] jllee@postech.ac.kr 